\title{
釧路地方気象台における強震動と弱震動に 対するサイト特性の評価
}

\author{
京都大学防災研究所* 山本みどり・岩 田 知 孝・入倉孝次郎
}

\section{Estimation of Site Effects for Strong and Weak Ground Motions at Kushiro Local Meteorological Observatory}

\author{
Midori Yamamoto, Tomotaka Iwata and Kojiro Irikura \\ Disaster Prevention Reserch Institute, Kyoto University Gokasho, Uji, Kyoto 611, Japan
}

(Received May 24, 1995; Accepted September 12, 1995)

\begin{abstract}
We propose a new method to estimate site amplification effects at specific sites, separating source and propagation-path effects. First, we calculate "specified spectra" from a given source and propagation-path effects, with a fixed site effect of 2.0. Then, we include effects of rupture process into the "specified spectra" using the empirical Green's function method. Site effects can be defined as a ratio of observed seismic spectra to the "specified spectra". We applied this method to the ground motion data during the 1993 Kushiro-oki earthquake as strong motions and those of other small earthquakes as weak motions in the south-east area of Hokkaido. We found nonlinear site effects at the station KSR, in Kushiro city, where the maximum of horizontal amplitude was $711.4 \mathrm{~cm} / \mathrm{s}^{2}$ during the 1993 Kushiro-oki earthquake. The predominant frequency of the site effects became smaller and the amplification level of those at high frequencies became lower than those for the weak motions.
\end{abstract}

Key words: Site effect, Specified spectra, Stochastic simulation, Nonlinearity, Empirical Green's function method.

§1.はじめに

地震動が表層地盤によってどのような影響をうけるの かを検討することは强震動を予測するうえで大変重要で ある. 場所毎に表層地盤による地震動の增幅度（以下で はサイト特性）を正確に求めることは, 地震時の被害の 軽減と直接結びつけることが出来, 地震工学的見地から も意味のあることである.このサイト特性は, 表首地盤 の物理的特性の違いだけではなく，表層地盤に入射する 地震動の強さによっても異なることが知られている [例 えば, 井合 (1993)]. つまり, サイト特性は地震動強さに 対して非線形性を持っているのである。サイト特性を見 積るには，表層地盤入射前と通過後の地震動を比較すれ ばよい，それには鉛直アレー地震観測記録を用いて，地 中と地表での記録を比較するのが直接的である[例え ば, 佐藤・他 (1993)]. しかし, 鈶直アレーで観測してい る点は少なく，一般性を欠くので任意の場所でのサイト

* $\mathbf{T} 611$ 宇治市五ヶ庄
特性を見積る際に適用することは出来ない。そこで，地 表のみで得られた記録からサイト特性を抽出する方法が 必要である.

今までに，地表の強震動記録からサイト特性を求めた 研究例はいくつかある.コーダ波のスペクトル振幅を用 いて，全観測点の平均值に対する各観測点での増幅度を 見積り，それをサイト特性とみなす方法 [PHILLIPS and AKI (1986)] や，複数の地震における複数の観測点での 観測スペクトルから震源特性及び $Q$ 值之同時にサイト 特性を分離する方法 [岩田・入倉 (1986)] 等があげられ る.

一方, 実際のデータから地盤の非線形性を指摘した研 究例もあり, 最近では翠川 (1993)によってまとめられ ている. 例えば，時松・翠川 (1988) は, 塩釜港での強震 記録が振幅の増大とともにその卓越周期がのびる傾向が あることから，地盤の非線形性の影響を示唆している. Darragh and Shakal (1991) は, Loma Prieta 地震や Coyote Lake 地震等のデー夕の岩盤の観測点と 2 種類 
の堆積層上の観測点とのスペクトル比が，大きい地震動 が入射した場合と小さい地震動が入射した場合とで異な ること，その非線形性の有無が地盤の性質によることを 指摘している. また, CHIN and AKI (1991) では, 線形 領域でのサイト特性, 震源特性をそれぞれ見積り, 距離 減衰及び $Q$ 值を考慮して，サイト特性が線形挙動を示し た場合における地震動を推定し，それと観測記録とを比 較して, Loma Prieta 地震において堆積層上にある観測 点の地盤が非線形挙動をしたことを指摘している。この 論文では, 強震動の場合において, 弱震動の場合よりも 最大加速度值が減少することと卓越周波数が低周波数側 へ移行することが地盤の非線形性の根拠として挙げられ ている

強震動から解析的にサイト特性を抽出して地盤の非線 形性を議論するだけではなく, 理論的に非線形挙動を示 す地盤を伝播する波形の計算手法についてあ数多くの研 究がなされている．地盤の非線形性は応力一ひずみ関係 が比例関係でなくなることによって起こる．その履歴曲 線の非線形性を考慮して表首地盤のモデルを作り地表面 での記録を計算する [例えば, SCHNABEL et al. (1972)]. このような計算を用いて地盤の非線形性が地震動に与え る影響について議論している論文あある。それによると 非線形性を考慮した場合の方が，しない場合よりも最大 加速度值が減少すること及び卓越周波数が低下すること が挙げられており，理論計算でも観測記録の解析で示さ れたあのと同じ特徵が見えることが指摘されている $[\mathrm{Yu}$ et al. (1992)].

1993 年 1 月 15 日, 釧路沖地震 (マグニチュード 7.8) が起き，震央に近い釧路市では震度 6 を記録した。この 地震で釧路気象台建物内に設置された気象庁 87 型強震 計では最大水平加速度が $\mathrm{N} 90 \mathrm{E}$ 成分で $922.2 \mathrm{~cm} / \mathrm{s}^{2}$, 同 構内の地表に設置された建設省建築研究所の観測点では $\mathrm{N} 63 \mathrm{E}$ 成分で $711.4 \mathrm{~cm} / \mathrm{s}^{2}$ という非常に大きな振幅が記 録された。サイト特性の入射地震動強さ依存性を調べる ため, 強震動と弱震動それぞれのサイト特性を求めて比 較する必要がある，従来の観測スペクトルからサイト特 性を抽出する方法では, 全ての観測点において震源特性 が同一であるとみなせることを仮定しており，かつ，サ イト特性はある基準観測点との比として求まる. しかし ながら，釧路沖地震の断層の大きさは，約 $40 \mathrm{~km} \times 60$ km [TAKEO et al. (1993)] であり, 点震源とみなすこと は出来ない. また, 震源す $107 \mathrm{~km}$ と深いものの, 釧路 は震央のすぐ北であり，断層の真上に位置している，釧 路に近い気象庁の観測点だけをみても, 根室は断層のほ ぼ真東, 網走はほぼ真北, 浦河はほぼ真西にあり, ディ レクティビティ等の震源の破壊過程の影響が全ての観測
点において異なると考えられる．また，観測点根室は先 新第三紀の堆積岩上にあり（験震時報第 37 巻第 3 号, 地質調查所地質図）比較的硬質な地盤上にあると考えら

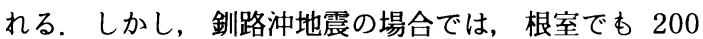
$\mathrm{cm} / \mathrm{s}^{2}$ 以上の振幅を記録しており, 根室のサイト特性が 非線形挙動することが十分考えられる．強震動之弱震動 のサイト特性を基準点との比をとって比較する場合に基 準点となりえるのは，その観測点の両サイト特性とも線 形挙動をしている場合である，よって，この釧路沖地震 の場合では根室を基準点とすることは出来ない.

以上のようなことから，本研究では各観測点に対して 震源特性之伝播経路特性を独立に定めた後，それらを観 測記録から分離しててサイト特性を決定する方法を提案 する．更に断層が大きい地震の場合は震源の破壊過程の 各観測点での影響を考虑した震源特性を評価した後サイ 卜特性を求める．釧路沖地震において，非常に大きな振 幅を記録した釧路気象台のサイト特性を求めるため,こ の方法を釧路沖地震とそれ以外の中小地震の記録に別々 に適用し, 強震時之弱震時のサイト特性の違いについて 比較検討した。 さらに比較のために北海道南東部に位置 する 3 つの観測点についてあ同様の解析をおこなった.

\section{§2. 方法}

本研究ではサイト特性を求める時の基準として，対象 とする地震について, 観測点が自由表面（サイト特性が 2.0 である面）にあると仮定した場合に地表で得られる と考えられる '基準スペクトル'というものを導入する. その基準スペクトルと観測スペクトルとの比をサイト特 性と定義する.

ここでいう基準スペクトルとは，対象とする地震の地

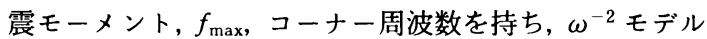
に基づくスペクトル特性にサイト特性として 2.0 , 更に 距離減衰と $Q$ 值による減衰を考慮したものである.

はじめに，基準スペクトルの求め方を述べる． $\mathrm{S}$ 波主 要部分の観測スペクトル $A(f)$ は周波数領域において

$$
A(f)=C M_{0} S(f) P(f) R^{-1} \exp \left(\frac{-\pi f R}{Q_{\beta}(f) \beta}\right)
$$

と表現される [BOORE (1983)]. ここで $f$ は周波数， $\beta$ は $\mathrm{S}$ 波速度, $R$ は震源距離, $M_{0}$ は地震モーメントである. また, $S(f)$ は $\omega^{-2}$ モデルに従う震源特性で， $f_{c}$ をコー ナ一周波数とすると,

$$
S(f)=\frac{(2 \pi f)^{2}}{1+\left(\frac{f}{f_{c}}\right)^{2}}
$$

となる，更に高域遮断フィルター $P(f)$ は， 

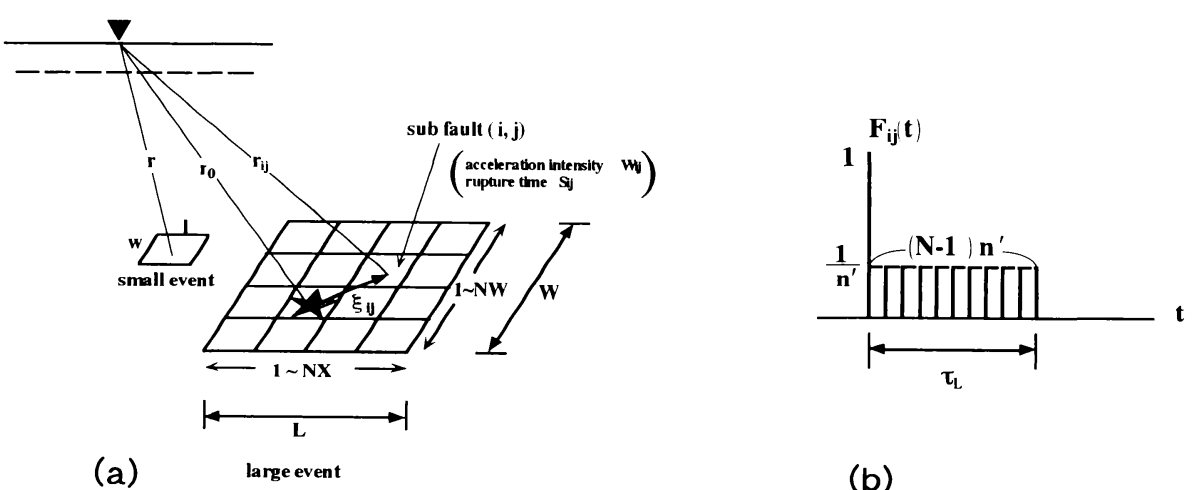

(b)

Fig. 1. (a) Schematic illustration of the Green's function method. The fault areas of the mainshock and a small event are defined to be $\mathrm{L} \times \mathrm{W}$ and $1 \times \mathrm{W}$, respectively. (b) $F_{i j}(t)$, a filtering function to adjust a difference in slip time function between the mainshock and the small event (after IRIKURA, 1986).

$$
P(f)=\frac{1}{1+\left(\frac{f}{f_{\max }}\right)^{n}}
$$

と表され, BOORE (1983) に従い, $n=1$ としている. その 他の係数である $C$ は,

$$
C=\frac{R_{\phi \theta} F_{s} P_{R}}{4 \pi \rho \beta^{3}}
$$

となり, $R_{\phi \theta}$ はラディエーションパターンの係数, $F_{s}$ は サイト特性を表す係数, $P_{R}$ はエネルギー分配の係数, $\rho$ は密度である.

そして, この式に対象とする地震の地震モーメント， コーナー周波数, $f_{\text {max }}$ を代入し, 別に求めた $Q$ 值を考慮 する. 更に,

$$
F_{s}=2.0
$$

とすると, $A(f)$ は, 観測点が自由表面にある場合に得ら れると期待されるスペクトルである. このスペクトルを 基準スペクトルとする. 対象とする地震の断層が小さく 点震源とみなせる場合はディレクティビティなどの震源 の破壊過程の影響は観測点毎に違いが小さいといえるの で，この基準スペクトルと観測スペクトルとの比をその ままサイト特性とする.

次に, 対象とする地震の断首が大きく点震源とはみな せない場合を考える.この場合は, 経験的グリーン関数 法 [IRIKURA (1986)] を用いることにより震源の破壊過程 の各観測点における影響を考慮した基準スペクトルを求 め, それと観測スペクトルとの比をサイト特性とする. 経験的グリーン関数法とは, 地震の相似則に基づいて, 小さい地震の地震波形を足し合わせて, 大きい地震の地 震波形を合成する方法である.この合成法は大きい地震 と小さい地震の間に (5), (6) 式のような相似則が成立す ることに基づいている.

$$
\begin{aligned}
& \frac{U_{L}}{U_{S}}=\frac{M_{L}}{M_{S}}=c N^{3} \\
& \frac{A_{L}}{A_{S}}=\left(\frac{M_{L}}{M_{S}}\right)^{1 / 3}=c N
\end{aligned}
$$

ここに, $U_{L}, U_{S}$ は大きい地震と小さい地震それぞれの低 周波振幅スペクトルレベル, $A_{L}, A_{S}$ はそれぞれの高周波 振幅スペクトルレベル， $M_{L}, M_{S}$ はそれぞれの地震モー メント, $c$ は大きい地震と小さい地震のストレスドロッ プの比を表す.

このような関係が成り立つ 2 つ地震の断層の大き さの空間的関係は, Fig. 1(a)のようになる.はじめに時 間的に小さい地震を大きい地震のライズタイムに合わせ て足し合わせる.この時, 小地震に関して時間的に重み を一椂に足すのではなく, Fig. 1(b)のような重みを付け れば, 合成された波形む $\omega^{-2}$ モデルに基づくような波形 が得られる. 次に断層面全体からの地震動の計算を行な j. KAKEHI and IRIKURA (1994) ではこの足し合わせを する時, それぞれの小断層について破壊開始時刻 $\left(s_{i j}\right)$ と 高周波発生の重み $\left(w_{i j}\right)$ をエンベロープインバージョン により求めている. また, 断層の分割のしかたは, 大き い地震のストライクの方向に $N X$ 個, ディップの方向に $N W$ 個, スリップ量の比として $N T$ を考えると,

$$
\begin{gathered}
A(t)=c \sum_{i=1}^{N X} \sum_{j=1}^{N W} w_{i j} \frac{r}{r_{i j}} F_{i j}(t)^{*} a(t) \\
F_{i j}(t)=\delta\left(t-t_{i j}\right)+\frac{1}{n^{\prime}} \sum_{k=1}^{(N T-1) n^{\prime}} \\
\delta\left(t-t_{i j}-\frac{(k-1) \tau_{L}}{(N T-1) n^{\prime}}\right) \\
t_{i j}=\frac{\left(r_{i j}-r_{0}\right)}{\beta}+s_{i j}
\end{gathered}
$$

という式が成り立つ.ここで, $A(t), a(t)$ はそれぞれ大き 
い地震と小さい地震の波形, $r$ は観測点における小さい 地震の震源距離, $r_{i j}$ は小断層 $i$ 之観測点 $j$ までの距離, $\beta$ は $\mathrm{S}$ 波速度， $\tau_{L}$ は大きい地震のライズタイムを表す。 尚, $n^{\prime}$ を導入するのは時間的に足し合わせることによっ て発生する周期性を解析対象周波数範囲外にするためで ある.

経験的グリーン関数法を用いて足し合わせをするに は, 小地震からの波形が必要である. そこで小地震を想 定した基準スペクトルを持つ波形を確率的波形作成法 [BOORE (1983)] を用いて求める.この方法はランダムノ イズから任意のスペクトル振幅と継続時間をもつような 波形を作り出すむのである．まず，ランダムノイズに時 間領域でウィンドウをかける. その結果得られるスペク トル振幅が基準スペクトルに平均的に一致するように周 波数領域で変形し，それを逆フーリエ変換することに よって時間領域での波形を求めている. 逆フーリ工変換

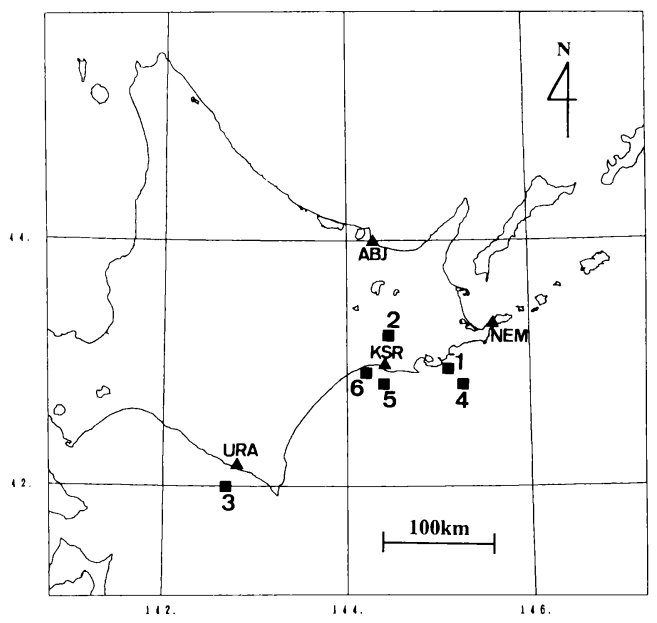

Fig. 2. Locations of observation stations (A) and epicenters $(\boldsymbol{\square})$ analysed in this study.
した後, 継続時間は初めに仮定したものと大きく変わら ないことを目で確認した.

ランダムノイズにかけるウィンドウ $w(t)$ は, BoorE (1983) より,

$$
\begin{aligned}
& w(t)=a t^{b} \exp (-c t) H(t) \\
& a=\left\{\frac{(2 c)^{2 b}+1}{\Gamma(2 b+1)}\right\}^{1 / 2} \\
& b=\frac{-\varepsilon \ln (\eta)}{1+\varepsilon(\ln (\varepsilon)-1)} \\
& c=\frac{b}{\varepsilon} T_{d}
\end{aligned}
$$

という式で求めている.ここで, $H(t)$ はステップ関数, $\Gamma(t)$ はガンマ関数をそれぞれ表し, $\eta=0.05, \varepsilon=0.2$ とし ている.

また， $T_{d}$ は継続時間であり，これあ BooRE (1983)に 従い,

$$
T_{d}=\frac{2}{f_{c}}
$$

を用いている.

このようにして確率的に求めた波形を小断層からの波 とする.これらを大きい地震の破壊過程に合わせて経験 的グリーン関数法を用いて足し合わせると, サイト特性 が 2.0 であるような大地震の波形が求められる. このよ うにして合成された波形のスペクトルを大きい地震の基 準スペクトルとする.

\section{§3. 解析}

強震動のサイト特性を求めるのに釧路沖地震を用いる ため, 弱震動のサイト特性を求めるのには, 釧路沖地震 と震央が比較的近いマグニチュード5〜6の 4 個の中小 地震を用いることにした (Table 1 の no. 1〜4). 深さに 関しても, 釧路沖地震が $107 \mathrm{~km}$ と深発であったので,

Table 1. List of magnitude, depth and values of maximum horizontal acceleration at each site of all earthquakes used in this study.

\begin{tabular}{c|c|c|c|c|c|c|c|c}
\hline \multirow{2}{*}{ no. } & \multirow{2}{*}{ event } & \multirow{2}{*}{$\begin{array}{c}\text { magnitude } \\
<\text { JMA }>\end{array}$} & \multirow{2}{*}{$\begin{array}{c}\text { depth } \\
(\mathbf{k m})\end{array}$} & \multicolumn{5}{|c}{ max. of acc. (cm/s/s) } \\
\cline { 5 - 8 } & & & KSR & URA & NEM & ABJ & KUS \\
\hline 1 & $91 / 10 / 18$ & 5.3 & 59.7 & 44.3 & 1.47 & 21.4 & 2.93 & 41.8 \\
2 & $91 / 10 / 25$ & 6.1 & 104.9 & 103.1 & 11.7 & 5.14 & 1.59 & 105.7 \\
3 & $91 / 11 / 27$ & 6.4 & 63.7 & 25.4 & 194.7 & 2.57 & 3.14 & 21.1 \\
4 & $92 / 03 / 31$ & 5.3 & 45.5 & 13.3 & 2.96 & 33.1 & 1.85 & 18.7 \\
5 & $93 / 01 / 15$ & 7.8 & 107.9 & 726.0 & 265.6 & 216.4 & 21.3 & 922.2 \\
6 & $93 / 02 / 04$ & 4.9 & 95.0 & 77.0 & 2.85 & 1.47 & & 95.8 \\
\hline
\end{tabular}


acceleration spectra
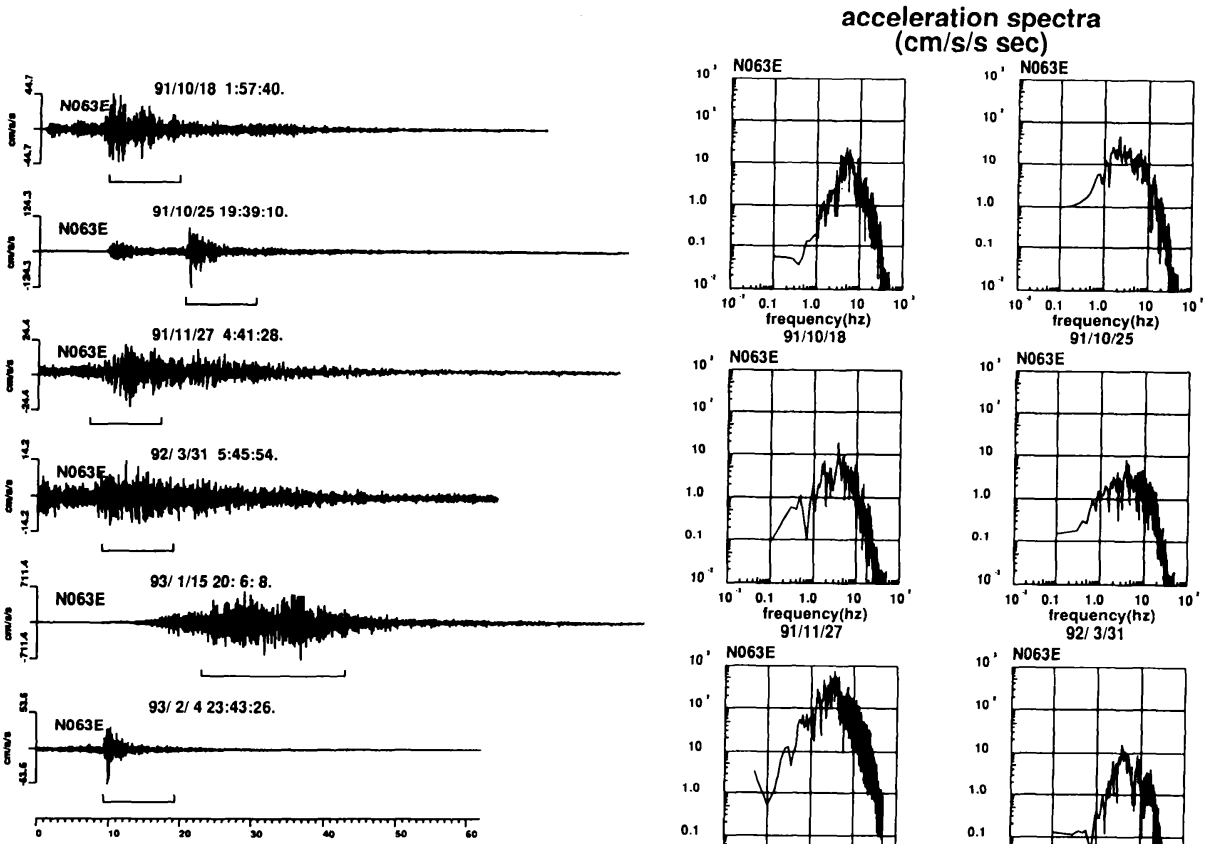

(a)
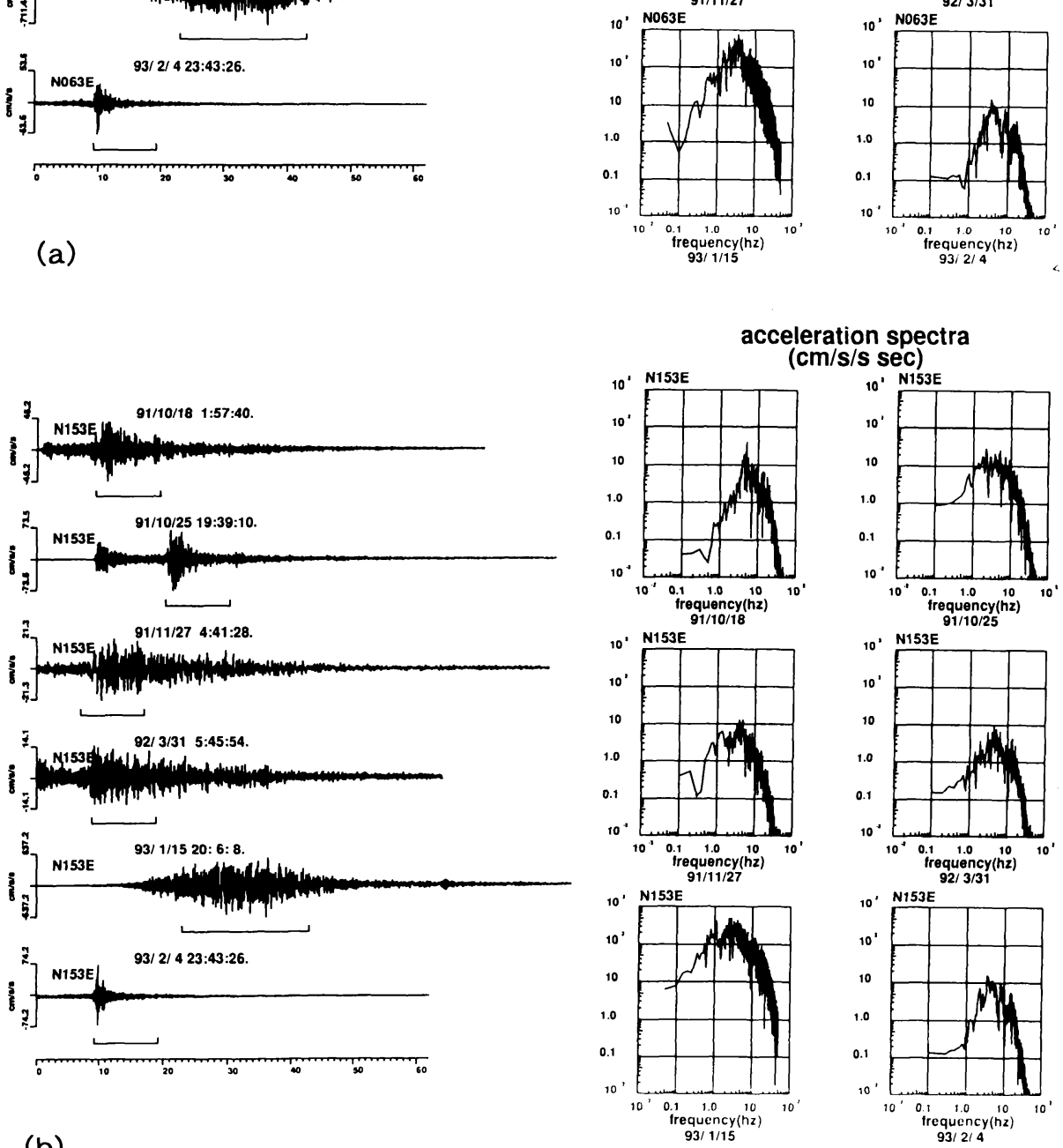

(b)

Fig. 3. Seismograms and acceleration spectra observed at the KSR station for all events, (a) N63 E-component and (b) N153E-component, respectively. Each line under seismograms indicates a part of the record used for the Fourier amplitude spectrum. 
中小地震についても深さ $50 \sim 100 \mathrm{~km}$ の比較的深いも のを選んだ。観測点は釧路 (KSR), 根室 (NEM), 浦河 (URA), 網走 (ABJ) の 4 点で, KSR では, 釧路地方気象 台構内の地表に設置されている建設省建築研究所釧路観 測点 (SMAC-MD 型) の記録を用い，その他の点では， JMA 87 型の記録を用いた. 観測点と震央の位置を Fig. 2 に示し, 用いた地震のリストをTable 1 に記す。観測 スペクトルは加速度記録の $\mathrm{S}$ 波主要部分の水平 2 成分 の二乗和の平方根とした． $\mathrm{S}$ 波主要部分全体を解析する ため, 釧路沖地震では $\mathrm{S}$ 波到達時刻より 20 秒間, その 他の中小地震では 10 秒間を解析区間とした。この解析 区間をとる時, 全てのデータに前後 1 秒ずっのサイン型 のウィンドウをかけた．また，全ての地震で SN 比が十 分ある $1.0 \sim 10.0 \mathrm{~Hz}$ の周波数帯を解析の対象とした. それぞれの地震の KSR における波形と解析区間および スペクトルを Fig. 3 に示す.

はじめに上記の 4 個の中小地震の観測スペクトルか らこの地域における $Q$ 值を分離する. その方法は岩田・ 入倉 (1986) に基づいて次に示される. $\mathrm{S}$ 波主要部分の

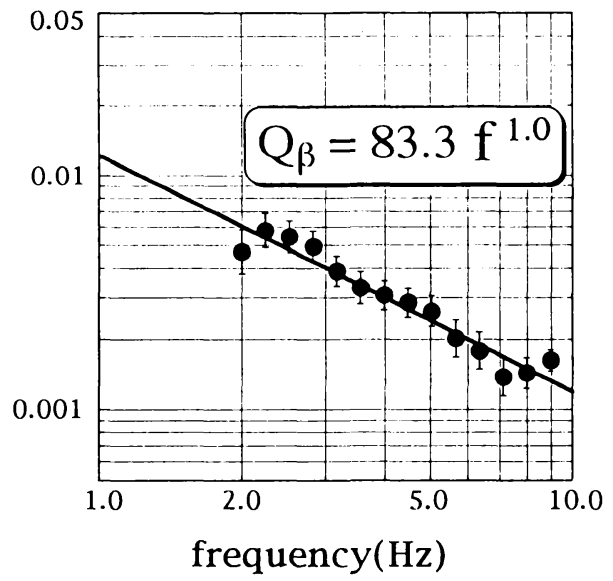

Fig. 4. $Q^{-1}$-values for $\mathrm{S}$-wave determined by the inversion in this study. Vertical bars are standard deviation, and solid line is the best fitting line.
観測スペクトル $O_{j}^{i}$ は

$$
O_{j}^{i}(f)=S^{i}(f) G_{j}(f)\left(R_{j}^{i}\right)^{-1} \exp \left(-\frac{\pi f R_{j}^{i}}{\beta Q_{\beta}(f)}\right)
$$

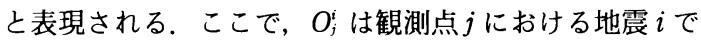
の $\mathrm{S}$ 波主要部分の観测スペクトル特性, $S^{i}$ は地震 $i$ での 震源スペクトル特性, $G_{j}$ は観測点 $j$ の観測点近傍のスペ クトル特性, $R_{j}^{i}$ は観测点 $j$ における地震 $i$ での震源距 離, $\beta$ は $\mathrm{S}$ 波速度である.

この $i \times j$ 個の式の両辺の対数をとって線形化すると

$$
\log O_{j}^{i}=\log S^{i}+\log G_{j}-\log R_{j}^{i}-\left(\frac{\pi f R_{j}^{i}}{\beta Q_{\beta}}\right) \log e
$$

になる.これらの式に対して，最小二乗法を用いて， $S^{i}$, $G_{j}, Q_{\beta}$ を分離する. この時, 拘束条件として, 比較的硬質 な地盤上にある観測点 NEM のサイト特性を 2.0 と仮定 して計算しているのでここで得られる他の地点のサイト 特性は相対的な值となる，Q值を分離した結果，2.0〜 $10.0 \mathrm{~Hz}$ で安定な解が得られたので, 解析区間を $1.0 \mathrm{~Hz}$ まで広げるため, 2.0〜 $10.0 \mathrm{~Hz}$ で得られた解を直線近似 し，1.0 Hz までその直線をのばして，1.0〜 $10.0 \mathrm{~Hz}$ にお ける $Q$ 值を求めた. その直線の式は

$$
Q_{B}(f)=83.3 \times f^{1.0}
$$

である. 本研究で求められた $Q$ 值を Fig. 4 に示す.

次に，基準スペクトルの求め方を記す，まず，各地震 におけるパラメーターの決め方を述べる.コーナー周波 数は観測記録の変位スペクトルから直接目で読み取っ た. 地震モーメントは, P.D.E に記載されていた 1991 年11月 27 日の地震のモーメント值を基準とし, 他 の地震については, 基準の地震との変位スペクトル のフラットレベルの比から推定した. $f_{\max }$ は, F ACCIOLI (1986) に基づき,

$$
f_{\max }=7.31 \times 10^{3} \times M_{0}^{-0.12}
$$

という式より求めている. その他の係数についてである が, ラディエーションパターンの係数として 0.64 [(BOORE and BOATWRIGHT (1984)]，エネルギー分配の係 数としては 1.0 , 密度は $2.7 \mathrm{~g} / \mathrm{cm}^{3}, \mathrm{~S}$ 波速度は 4.28 $\mathrm{km} / \mathrm{s}$ を用いた.

Table 2. List of seismic moment, corner frequency and $f_{\max }$ of each event determined in this study.

\begin{tabular}{c|c|c|c|c}
\hline no. & event & $\begin{array}{c}\text { seismic moment } \\
\left(\mathbf{1 0}^{17} \mathbf{N m}\right)\end{array}$ & $\begin{array}{c}\text { comer frequency } \\
(\mathbf{H z})\end{array}$ & $\begin{array}{c}\text { fmax } \\
(\mathbf{H z})\end{array}$ \\
\hline 2 & $91 / 10 / 25$ & 4.38 & 1.05 & 8.07 \\
3 & $91 / 11 / 27$ & 71.0 & 0.41 & 5.78 \\
4 & $92 / 03 / 31$ & 2.20 & 0.92 & 8.77 \\
6 & $93 / 02 / 04$ & 0.51 & 2.0 & 10.44 \\
\hline
\end{tabular}




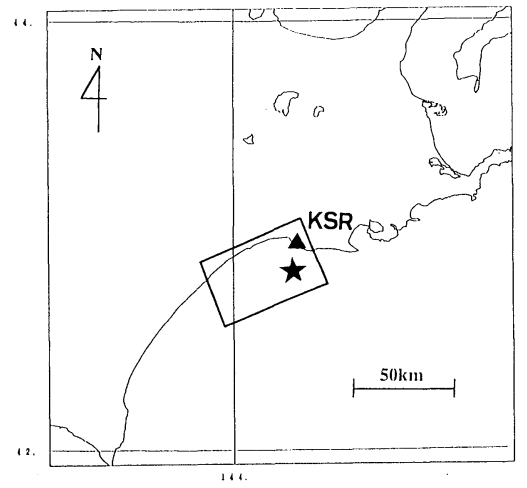

(a)

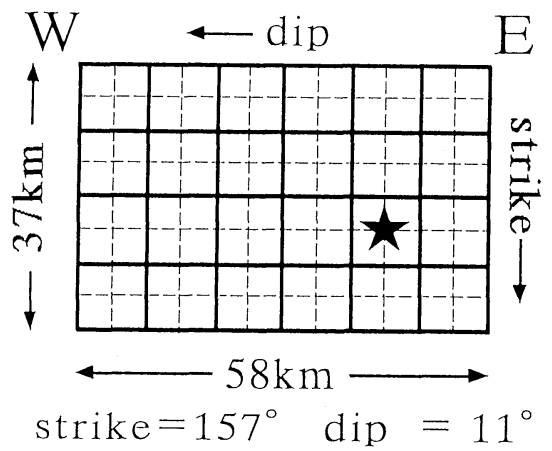

(b)

Fig. 5. (a) Location of fault plane of the 1993 Kushiro-oki earthquake. (b) The meshes of the acceleration intensity and the rupture time (Solid line). The size of each subfault used in the empirical Green's function method (Dotted line). Starting point of the rupture $(\star$ ) (after KAKEHI \& IRIKURA, 1994).

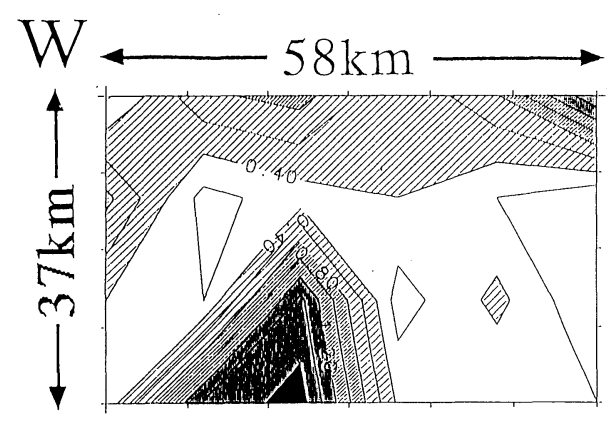

(a)

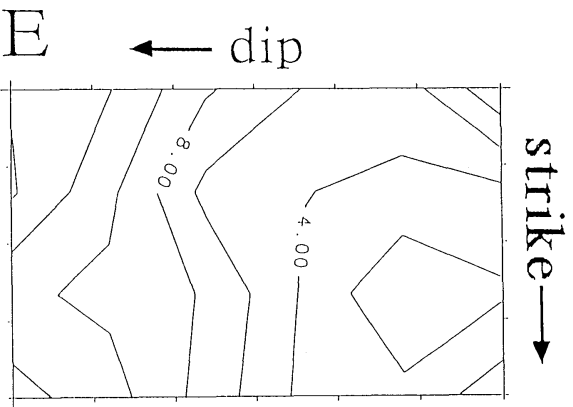

(b)

Fig. 6. Distribution of acceleration intensity (a) and rupture times (sec) (b) obtained by KAKEHI and IRIKURA (1994).

$Q$ 值を分離した 4 個の中小地震のうち, 1991 年 10 月 18 日の地震に関しては, コーナー周波数と変位スペ クトルのフラットレベルを読むことが出来なかったの で, 弱震動のサイト特性を求めるのには使用しなかっ た. よって，3個の地震に関して, 基準スペクトルと観 測スペクトルとの比を求め, その相乗平均を弱震動のサ イト特性とし， 3 個の地震に関する標準偏差を弱震動の サイト特性のそれらとした. Table 2 に読み取ったパラ メーターを記す.

次に, 釧路沖地震のサイト特性の求め方について述べ る. 釧路沖地震の断層モデルは, KAKEHI and IRIKURA (1994) に従った. ストライクは 157 度, ディップは 11 度であり, 大きさはストライクの方向に $37 \mathrm{~km}$, ディッ プの方向に $58 \mathrm{~km}$ である. その他のパラメーターは, $N X=8, N W=12, N T=8, c=12, \tau_{L}=4.8 \mathrm{~s}, n^{\prime}=80$ と求 められており, 本研究であこの值を用いている. 断層の
位置を Fig. 5(a) に，小断層への分割のしかたとエンベ ロープインバージョンでのメッシュの切り方を Fig. 5 (b) にそれぞれ示す. Fig. 6 は高周波発生の重みと破壊 開始時刻である。また，小断層からの波形として KAKEHI and IRIKURA (1994) では釧路沖地震の最大余震 である 1993 年 2 月 4 日の記録を用いている. 本研究で は，この地震を想定した基準スペクトルと平均的に一致 するスペクトルを持つような波形を確率的波形作成法 [BOORE (1983)] で作り，これを経験的グリーン関数とし ている.この地震の基準スペクトルは弱震動の場合と全 く同様に求めている. 確率的波形作成法でランダムノイ ズを発生させる時に用いたランダム変数によって波形が 異なり，一意には決まらない，そこで，ランダム変数を 変えたランダムノイズを 20 個作り，そのうち基準スぺ クトルによく一致しているすのを目視で判断し， 5 個の 波形を選んだ。選ばれた 5 個の波形それぞれを経験的グ 
during the 1993 Kushiro-oki eq.

- during other earthquakes
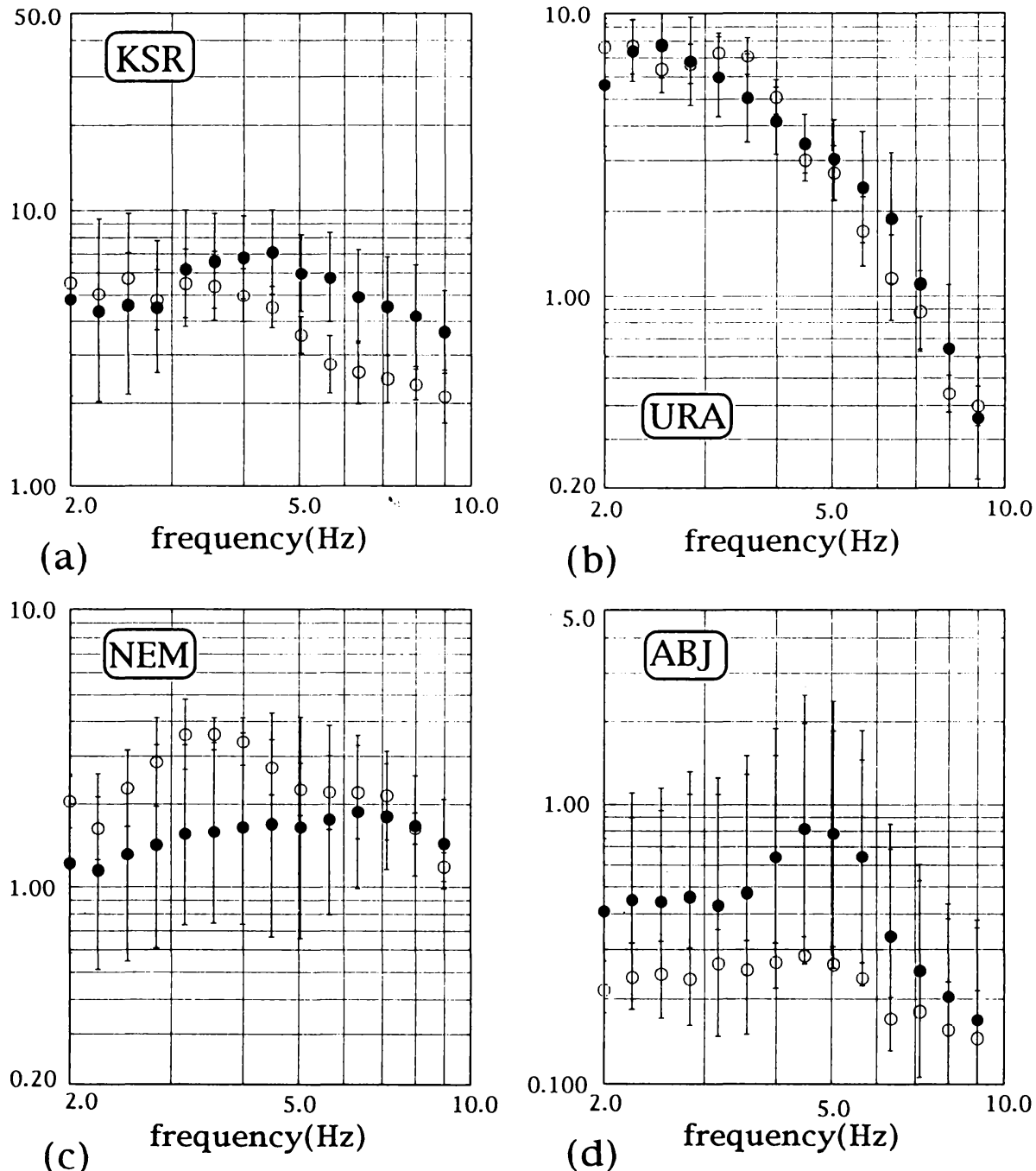

Fig. 7. Site effects for the 1993 Kushiro-oki earthquake $(O)$ and other earthquakes $(\bullet)$ at the stations (a) KSR, (b) URA, (c) NEM and (d) ABJ.

リーン関数として足し合わせ，釧路沖地震時のサイト特 性が 2.0 であるような波形を 5 波作った。 それらの 5 個 の波形のスペクトルの相乗平均を釧路沖地震における基 準スペクトルとし, 観測スペクトルとの比を強震動のサ イト特性とした.その 5 個の波形の標準偏差を強震動の サイト特性のそれらとした。

\section{§4. 結果}

釧路沖地震による強震動時と中小地震による弱震動時 のサイト特性とそれぞれの標準偏差を Fig. 7 に示す. 解
析区間を $1.0 〜 10.0 \mathrm{~Hz}$ としていたが, $1.0 〜 2.0 \mathrm{~Hz}$ にお いて信頼できる結果が得られなかったので, $2.0 〜 10.0$ $\mathrm{Hz}$ での結果を示す. 釧路沖地震時に $21.0 \mathrm{~cm} / \mathrm{s}^{2}$ の最大 水平加速度振幅を記録した ABJ (Fig. 7(d)) では, 弱震動 のサイト特性のばらつきが大きく, 強震動のサイト特性 はそれらの標準偏差内であり, 両サイト特性の間に有為 な差は見られない.この弱震動のサイト特性のばらつき が大きいのは, 地震数が少ないことと, コーナー周波数 とQ 值の見積りが不正確であったことが理由だと考え られる.また $216.4 \mathrm{~cm} / \mathrm{s}^{2}$ を記録した NEM (Fig. 7(c)) 


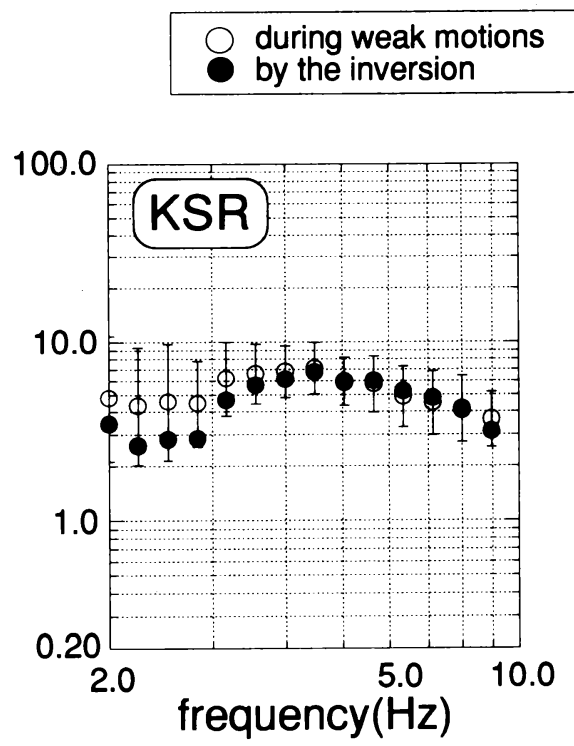

Fig. 8. Comparison between site effects using weak motions $(O)$ and those determined by the inversion at the KSR station ( $\bullet$ ). The latter is obtained as the ratio to the NEM station. Vertical bars show standard deviations of the site effects by the inversion.

でも， $265.6 \mathrm{~cm} / \mathrm{s}^{2}$ を記録した URA (Fig. 7(b)) でも同 様に標準偏差を越えるほどの大きな差は見られなかっ た. 一方, $711.4 \mathrm{~cm} / \mathrm{s}^{2}$ を記録した KSR (Fig. 7(a)) では 低周波数側では標準偏差内にあるが, 高周波数側で両サ イト特性の間に有為な差が見られ，地盤が次のような非 線型挙動を示したことがわかった. KSRでは, 強震動の サイト特性が弱震動のサイト特性より, $4.0 \mathrm{~Hz}$ 以上の高 周波で有意に小さい，また, 弱震動のサイト特性のピー クが $4.5 \mathrm{~Hz}$, 強震動では $2.5 \mathrm{~Hz}$ と低周波数側にずれて いる. Fig. 8 では, KSR に関して弱震動のサイト特性と $Q$ 值と同時に分離されたサイト特性を比較している， $Q$ 值之同時に分離されたサイト特性が NEM のサイト特性 を 2.0 と固定した相対值であることを考慮し, 両サイト 特性を正確に比較するため, $Q$ 值と同時に分離されたも のを NEM のサイト特性で補正している. 両サイト特性 の間に有意な差はなく, 点震源の場合では従来の方法と 整合性があるといえる. 飛田・杉村 (1994) は一次元地 盤非線形モデルで釧路気象台における釧路沖地震時の波 形を計算している．釧路気象台敷地内のボーリング調査 の結果をもとに, 地下 $17.24 \mathrm{~m}$ に 波速度 $650 \mathrm{~m} / \mathrm{s}$ の 基盤層（浦幌首群）があるとして，その上を 3 層の堆積 層に分けた非線形モデルを作り，釧路沖地震を想定した 入射波を入れた時と，小振幅の入射波を入れて線形応答 during the 1993 Kushiro-oki eq.

during other earthquakes

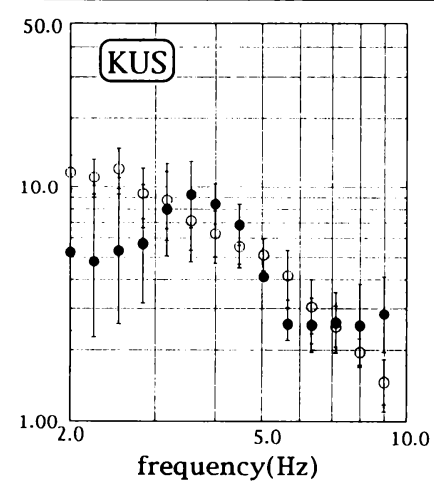

Fig. 9. Site effects for the 1993 Kushiro-oki earthquake $(\bigcirc)$ and other earthquakes (0) at the KUS station. Bar lines indicate standard deviations.

した時と両方において地表面での波形とそれぞれの層で の波形を計算している．その両方の入射波に対して基盤 層での波形と地表面での波形の加速度スペクトルの比を とり，比較している．それによると固有周期が小振幅の 波を入力した時に比べて 0.25 秒から 0.35 秒にずれるこ とが指摘されており, 更に, 0.25 秒以下で概ね小振幅の 波を入力した時の応答より釧路沖地震時の応答の方が小 さくなっている.これも本研究の結果と整合性があると いえる.

\section{§ 5. JMA87 型の記録との比較}

今まで釧路の記録として建設省建築研究所の記録 (KSR) を用いてきた。ここで，この KSR と同じ釧路地 方気象台構内の建物 1 階に設置された JMA87 型の記録 (KUS) に同じ解析を試みて, 結果を比較した. 両観測点 は $20 \mathrm{~m}$ 程しか離れていないので KUSでも KSR の場 合と同じ基準スペクトルを用いた.

Fig. 9 に KUS における釧路沖地震時のサイト特性と 弱震動のサイト特性を示す. KSR では $4.0 \mathrm{~Hz}$ 以上の高 周波において強震動のサイト特性のほうが小さくなると いう差がみられたが, KUSではみられない, 卓越周波数 も弱震動で $3.5 \mathrm{~Hz}$, 強震動で $2.5 \mathrm{~Hz}$ と低下している. 川瀬 (1994) は北海道内 10 点の気象台のサイト特性を 地震毎の震源特性, 幾何減衰を考虑し, 全観測点の平均 的なサイト特性を持つスペクトル特性と観測スペクトル との比として求めている.これによると KUS では釧路 沖地震以外でのサイト特性の卓越周波数が $3.6 \mathrm{~Hz}$ ，釧路 沖地震では $2.8 \mathrm{~Hz}$ と低下していることを示し, 地盤や 


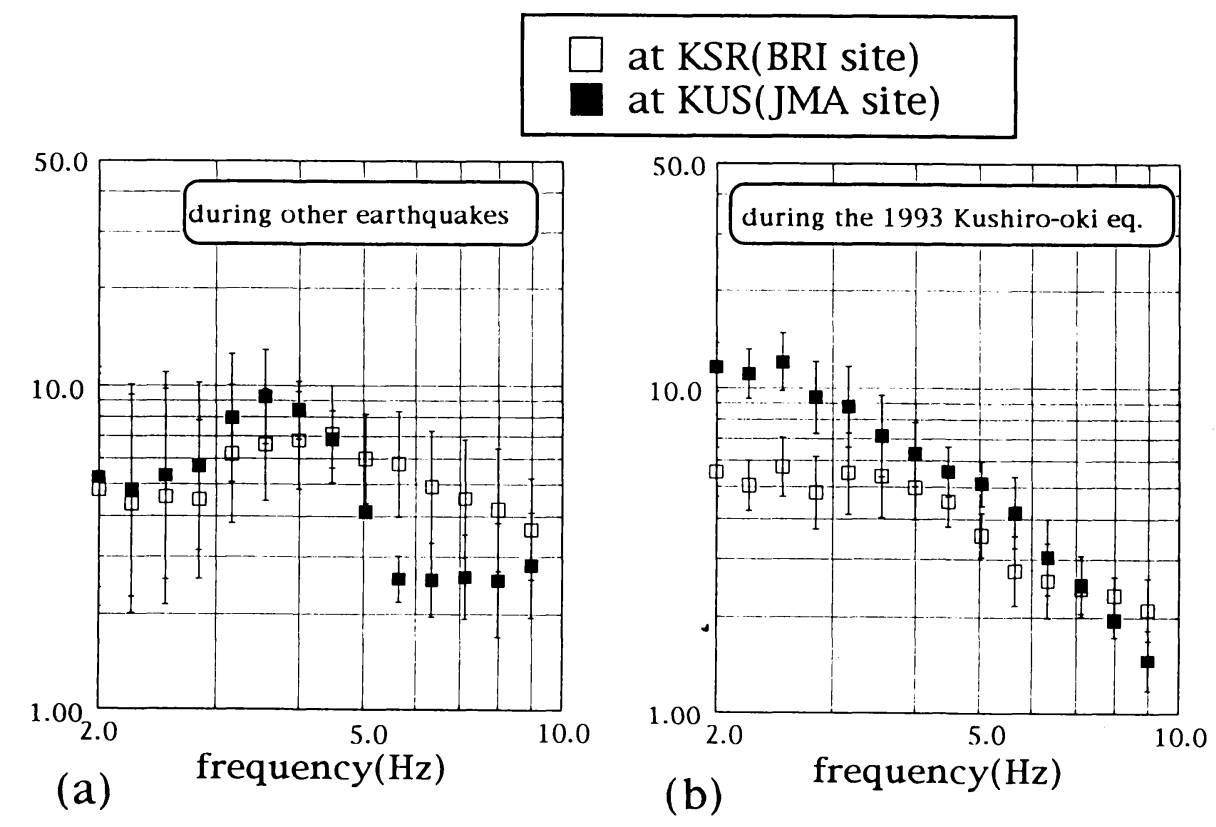

Fig. 10. Site effects at the KSR station $(\square)$ and the KUS station ( $\square$ ) for the 1993 Kushiro-oki earthquake (a) and for other earthquakes (b). Bar lines indicate standard deviations.

建屋応答の非線形化の可能性を指摘している.

また, Fig. 10(a) と Fig. 10(b) がそれぞれ KSR と KUS の弱震動のサイト特性と, 釧路沖地震時のサイト 特性である.これらの図から弱震動では, $5.0 \mathrm{~Hz}$ 以上の 高周波側で KSR のほうが大きく, 強震動では, 2.0 3.0 $\mathrm{Hz}$ でKUS の活が大きくなっていることがわかる. KSR と KUS の違いがそのまま建物によるものだとは 言えないが, この違いを地盤建物系の相互作用計算に よって説明を試みている研究がある. 壇 (1994) は, 釧路 地方気象台地下 $20 \mathrm{~m}$ での基盤波を求め, 地盤の非線形 応答解析により地表での波形を計算し，相互作用モデル の入力として，中小地震と釧路沖地震における KUS と KSR での波形を求めて比較している. 中小地震時と釧 路沖地震時の KSR と KUS の差は本研究とほぼ同じで ある．壇 (1994) によると中小地震に関しては，KSR と KUS の差はこの計算で説明出来ると結論している．ま た，釧路沖地震に関してはスペクトル振幅は計算と観測 とで一致していないが, 卓越周期のずれは再現出来た之 している. 従って本研究で推定した KSRにおけるサイ 卜特性は主として表層地盤の地震動応答であるのに対 し，KUSにおけるサイト特性は表層地盤のみでなく構 造物の影響も強く受けていると考えられる.

\section{§6. 結 論}

サイト特性の入射地震動強さ依存性を求めることを目
的として, サイト特性の絶対值を観測点毎に見積る方法 を提案した，その方法とは，地震毎に独立の方法で評価 した震源特性と伝播経路特性に加えて各観測点のサイト 特性が 2.0 として得られる基準スペクトルと観測スペク トルとの比をサイト特性と定義する．更に，断層を点震 源とみなせない場合は経験的グリーン関数法を用いて震 源の破壊過程を考慮して基準スペクトルを求め, 同様の 方法でサイト特性を想定する．この方法を，断層が大き くかつ強震動を与えた場合として 1993 年釧路沖地震 に，断層が小さく弱震動を与えた場合として北海道南部 で起こった 3 個の中小地震にそれぞれ適用し，釧路気象 台を含む北海道南東部の観測点における弱震動時と強震 動時でのサイト特性をそれぞれ求めた.

その結果, 釧路沖地震の際に $711.4 \mathrm{~cm} / \mathrm{s}^{2}$ の最大水平 加速度を記録した KSR では, 両サイト特性の間に次の ような違いがあることがわかった。

1. 高周波側で強震動時のサイト特性の方が小さくな る.

2. サイト特性のピークが強震動時の方が低周波数側 にずれる.

一方, NEM, ABJ, URA（釧路沖地震時の最大水平加 速度がそれぞれ $\left.216.4,21.0,265.6 \mathrm{~cm} / \mathrm{s}^{2}\right)$ では両サイト 特性の間に明確な違いは見られなかった。 また，釧路沖 地震の際に $922.2 \mathrm{~cm} / \mathrm{s}^{2}$ 記録した KUS のサイト特性の 間にも有意な差が見られた。この KUS の非線形性には, 
建物の影響があらわれている可能性がある.

\section{謝辞}

気象庁 87 型電磁式強震計データ及び建設省建築研究 所釧路観測点のデータを使わせて頂きました．記して感 謝致します。

本研究を進めるにあたって, 清水建設の川瀬博氏には 非常に有益な助言を頂き, 京都大学原子炋実験所の釜江 克宏氏には, 確率的波形作成法及び経験的グリーン関数 法に関して議論して頂きました。 心より感謝を申し上げ ます。

\section{文献}

Boore, D. M., 1983, Stochastic simulation of highfrequency ground motions based on seismological models of the radiated spectra, Bull. Seism. Soc. Am., 73, 1865-1894.

Boore, D. M. and J. BoAtwright, 1984, Average bodywave radiation coefficients, Bull. Seism. Soc. Am., 74, 1615-1621.

Chin, B. -H. and K. AкI, 1991, Simultaneous study of the source, path, and site effects on strong ground motion during the 1989 Loma Prieta earthquake: A preliminary result on pervasive nonlinear site effects, Bull. Seism. Soc. Am., 81, 1859-1884.

壇 一男, 1994, 釧路地方気象台建物の非線形相互作用 解析, 1993 年釧路沖地震に関する総合シンポジゥム, 85-92.

DARrgh, R. B. and A. F. Shakal, 1991, The site response of two rock and soil station pairs to strong and weak ground motion, Bull. Seisin. Soc. Am., 81, 1885-1899.

FAccioli, E., 1986, A study of strong motions from Italy and Yugoslavia in terms of gross source properties, Geophys. Monograph, 37, Maurice Ewing, AGU, 6, 297-309.

井合 進, 1993, 表層地質の非線形性について一最近の 研究加 一, 平成 4 年度文部省科学研究費補助金総合 研究 (A) 研究成果報告書一地震動に与える表層地質の 影響に関する総合的研究, 254-267.

IRIKURA, K., 1986, Prediction of strong acceleration motion using empirical Green's function, Proc. 7 th
Japan Earthq. Eng. Symp., 151-156.

岩田知孝・入倉孝次郎，1986，観測された地震波から， 震源特性・伝播経路特性及び観測点近傍の地盤特性を 分離する試み, 地震 2, 39, 579-593.

KAKEHI, Y. and K. IRIKURA, 1994, Estimation of high frequency wave radiation areas on the fault plane by the envelope inversion of acceleration seismograms, submitted to Geophysical Journal International.

川瀬 博, 1994, 北海道内の各地気象台における強震動 特性一1993 年釧路沖地震での釧路気象台の記録に着 目して, 日本建築学会構造系論文集, 459, 125-132.

気象庁地震課, 1972, 気象庁地震観測官署の地盤調査, 験震時報, 第 37 巻第 3 号, 113-115.

秓川三郎, 1993, 強震時にみられる地盤特性の非線形 性, 地震 2, 46, 207-216.

Phillips, W. S. and K. AK1,1986, Site amplification of coda waves from local earthquakes in central California, Bull. Seism. Soc. Am., 76, 627-648.

佐藤智美・佐藤俊明・川瀬 博, 1993, 堆積盆地におけ る $\mathrm{S}$ 波伝播の識別と土の非線形性の同定一足柄平野 久野地区の鉛直アレーで観測された弱震動と強震動の 分析一, 日本建築学会構造系論文報告集, 449, 55-68.

Schnabel, P. B., J. Lysmer and H. B. Seed, 1972, A computer program for earthquake response analysis of horizontally layered sites, College of Engineering University of California.

TAKEO, M., S. Ide and Y. Yoshida, 1993, The 1993 Kushiro-oki, Japan, earthquake : A high stress-drop event in a subductive slab, Geophys. Res. Lett., 20, 2607-2610.

地質調查所, $1: 500000$ 活構造図釧路昭和 60 年 3 月 20 日発行.

飛田 潤・杉村義広, 1994, 釧路地方気象台および釧路 市内の地震動特性における表層地盤の影響, 1993 年 釧路沖地震に関する総合シンポジゥム, 59-64.

時松孝次・翠川三郎, 1988, 地表で観測された強震記録 から推定した表層地盤の非線形性状，日本建築学会論 文報告集, 388, 131-137.

U.S.G.S., 1991, Preriminary Determination of Epicenters, no. 48-91, Dec. 19.

Yu, G., J G. Anderson and R. Siddharthan, 1992, On the characteristics of nonlinear soil response, Bull. Seism. Soc. Am., 83, 218-244. 